\title{
PENGARUH LINGKUNGAN KERJA TERHADAP KINERJA KARYAWAN PADA INDUSTRI KECIL KERAJINAN BATIK SIDOMUKTI DESA SIDOMUKTI KECAMATAN PLAOSAN KABUPATEN MAGETAN
}

\author{
Eko Budi Cahyono \\ Mahasiswa Prodi. Pendidikan Ekonomi IKIP PGRI MADIUN
}

\begin{abstract}
Abstrak: Penelitian ini bertujuan untuk mengetahui lingkungan kerja pada industri kecil kerajinan Batik Sidomukti Kabupaten Magetan, untuk mengetahui kinerja karyawan pada industri kecil kerajinan batik Sidomukti Kabupaten Magetan. Dan untuk mengetahui seberapa besar pengaruh antara lingkungan kerja terhadap kinerja karyawan pada industri kecil kerajinan Batik Sidomukti Desa Sidomukti Kecamatan Plaosan Kabupaten Magetan. Penentuan sampel di dalam penelitian ini menggunakan sampel bertujuan yaitu karyawan industri kecil kerajinan Batik Sidomukti yang berjumlah 35 karyawan. Pengumpulan data menggunakan metode kuesioner dan dokumentasi. Dalam menganalisis data pada penelitian menggunakan uji korelasi produk momen, uji F, dan uji t. Lingkungan kerja memiliki nilai rata-rata sebesar 47,63 dengan nilai maksimum 50, nilai minimum 40, standar deviasi 2,860, median 49,00, dan modus sebesar 5. Dari hasil deskripsi variabel lingkungan kerja diketahui bahwa responden cenderung setuju terhadap lingkungan kerja yang baik, karena lingkungan kerja yang baik dan kondusif dapat meningkatkan kinerja karyawannya dalam proses produksi yang telah dibebankan oleh perusahaan. Kinerja karyawan memiliki rata-rata sebesar 48,66, dengan nilai maksimum 50, nilai minimum 44, standar deviasi 1.804 , median 49,00 dan modus sebesar 50. Dari hasil deskripsi variabel kinerja karyawan diketahui bahwa responden cenderung mempunyai nilai (rata-rata 48,46). Dalam hasil anlisis regresi pada uji korelasi diperoleh nilai $r_{\text {hitung }}$ sebesar $0,393 \geq r_{\text {tabel }}$ sebesar 0,334 atau $\operatorname{Sig}_{\text {hit }} 0,000 \leq \operatorname{Sig}_{\text {prob }} 0,05$ artinya lingkungan kerja mempunyai hubungan terhadap kinerja karyawan pada industri kecil kerajinan Batik Sidomukti. Sementara pada uji Fisher diperoleh nilai $\mathrm{F}_{\text {hitung }}$ sebesar $6,024 \geq$ nilai $F_{\text {tabel }}$ sebesar 4,12 atau $\operatorname{Sig}_{\text {hit }} 0,000 \leq \operatorname{Sig}_{\text {prob }} 0,05$ artinya lingkungan kerja mempunyai pengaruh terhadap kinerja karyawan pada industri kecil kerajinan Batik Sidomukti. Dan pada uji $t$ diperoleh nilai $t_{\text {hitung }}$ sebesar 2,454 $\geq t_{\text {tabel }}$ sebesar 0,681 atau nilai $\mathrm{Sig}_{\text {hit }}$ sebesar $0,000 \leq \operatorname{Sig}_{\text {prob }} 0,05$ artinya ada beda pengaruh lingkungan kerja terhadap kinerja karyawan pada industri kecil kerajinan Batik Sidomukti.
\end{abstract}

Kata Kunci : Lingkungan kerja, Kinerja karyawan

\section{PENDAHULUAN}

Dalam hal bidang industri, kinerja karyawan merupakan faktor utama pengolahan bahan baku menjadi suatu hasil produk. Di mana para karyawan dituntut untuk dapat mengerjakan suatu pekerjaan yang berkualitas dan tepat waktu dalam memenuhi permintaan pasar. Dalam hal ini kinerja karyawan yang baik berpengaruh terhadap kelangsungan tumbuh kembangnya suatu perusahaan yang bergerak di bidang industri dalam menghasilkan suatu produk, karena bila kinerja karyawan kurang maksimal tidak menutup kemungkinan hasil dari perusahaan itupun menjadi kurang maksimal juga. Untuk itu pula perusahaan harus memperhatikan kebutuhan dari para tenaga kerjanya agar dapat bekerja semaksimal mungkin supaya 
dapat menghasilkan hasil produk yang berkualitas dan tepat pada waktunya.

Kinerja merupakan suatu fungsi dari motivasi dan kemampuan untuk menyelesaikan tugas atau pekerjaan. Seseorang sepatutnya memiliki derajat kesediaan dan tingkat kemampuan tertentu. Kesediaan dan keterampilan seseorang tidaklah cukup efektif untuk mengerjakan sesuatu tanpa pemahaman yang jelas tentang apa yang akan dikerjakan dan bagaimana mengerjakan.

Kinerja merupakan perilaku nyata yang ditampilkan setiap orang sebagai prestasi kerja yang dihasilkan oleh pegawai sesuai dengan perannya dalam instansi. Kinerja karyawan merupakan suatu hal yang sangat penting dalam upaya instansi untuk mencapai tujuan. Instansi umumnya mendasarkan perencanaan tujuan yang hendak dicapai di masa depan dengan perilaku yang diharapkan dari keseluruhan personel dalam mewujudkan tujuan tersebut. Tujuan utama penilaian kinerja pegawai adalah untuk memotivasi karyawan dalam mencapai sasaran operasi dan dalam memenuhi standar perilaku yang telah ditetapkan sebelumnya.

Menurut Moeheriono (2009: 60) kinerja atau perfomance merupakan gambaran mengenai tingkat pencapaian pelaksanaan suatu program kegiatan atau kebijakan dalam mewujudkan sasaran, tujuan, visi, dan misi organisasi yang dituangkan melalui perencanaan strategis suatu organisasi. Sedangkan menurut Oxford Dictionary dalam Moeheriono (2009: 61: kinerja (performance) merupakan suatu tindakan proses atau cara bertindak atau melakukan fungsi organisasi.

Kinerja merupakan hasil dan keluaran yang dihasilkan oleh seorang pegawai sesuai dengan perannya dalam organisasi suatu periode tertentu. Kinerja pegawai yang baik adalah salah satu faktor yang sangat penting dalam upaya instansi untuk meningkatan produktivitas.

Salah satu faktor yang dapat mempengaruhi kinerja karyawan adalah lingkungan kerja. Lingkungan kerja yang menyenangkan menjadi kunci pendorong bagi para karyawan untuk menghasilkan kinerja yang optimal.

Lingkungan kerja selalu berhubungan secara langsung para karyawan, karena lingkungan kerja merupakan tempat di mana para karyawan menyelesaikan tugas-tugas yang di bebankan suatu perusahaan. Dalam suatu lingkungan dibutuhkan suasana yang kondusif, penataan tempat untuk berbagai alat produksi sesuai dengan fungsi alatnya, dan juga di butuhkan suasana yang kondusif antar karyawan untuk memperlancar proses produksi maupun penyelesain pekerjaan.

Di samping itu lingkungan kerja juga merupakan tempat yang secara langsung dihadapai setiap saat oleh para tenaga kerja dalam melakukan pekerjannya, maka seharusnya para tenaga kerja akan merasa nyaman, dalam melakukan pekerjaannya. Apabila lingkungan di sekitarnya memberikan kenyamanan dalam melakukan dan menyelesaikan pekerjaannya, tidak menutup kemungkinan hasil kinerja karyawan akan berkualitas dan selesai tepat pada waktunya.

Lingkungan kerja dalam suatu perusahaan termasuk salah satu hal yang penting untuk diperhatikan. Meskipun lingkungan kerja tidak melaksanakan proses produksi dalam suatu perusahaan, namun lingkungan kerja mempunyai pengaruh langsung terhadap para karyawan yang melakukan proses produksi tersebut. Lingkungan kerja yang baik akan dapat meningkatkan kinerja sebaliknya lingkungan kerja yang kurang memadai akan menurunkan kinerja dan akhirnya menurunkan motivasi kinerja karyawan. Misalnya, seperti penerangan dalam lingkungan kerja yang buruk dapat menggangu karyawan dalam melaksanakan pekerjaannya.

Lingkungan kerja dapat mempengaruhi emosi pegawai. Jika pegawai menyenangi lingkungan kerja dimana dia bekerja, maka pegawai tersebut akan betah di tempat kerjanya untuk melakukan aktivitas sehingga waktu kerja dipergunakan secara efektif dan 
optimis prestasi kerja pegawai juga tinggi. Lingkungan kerja tersebut mencakup hubungan kerja yang terbentuk antara sesama pegawai dan hubungan kerja antar bawahan dan atasan serta lingkungan fisik tempat pegawaibekerja.

Menurut Alex Soemadji Nitisemito (1996: 109) lingkungan kerja adalah segala sesuatu yang ada di sekitar pekerja dan yang dapat mempengaruhi dirinya dalam menjalankan tugas-tugas yang di bebankan.

Dunia usaha saat ini sangat berkembang dengan pesat terutama perusahaan maupun industri kecil yang menghasilkan suatu produk. Akhir-akhir ini persaingan antar perusahaan semakin meningkat dengan seiring kemajuan zaman. Perusahaan ataupun industri haruslah mampu dalam mengikuti dan menyiasati bagaimana supaya perusahaan atau industri tersebut dapat bersaing dengan perusahaan yang menghasilkan produk yang sama ataupun serupa.

Jaka Pramana (2006: 42) istilah industri kecil menitik beratkan jumlah nilai investasi untuk mesin dan peralatan (tidak termasuk tanah, gedung, dan kendaraan), besar tidak lebih dari Rp 25 juta sampai Rp 70 juta. Lepas dari segala istilah tersebut pemerintah saat ini yang penting adalah mencari cara bagaimana industri dapat dikembangkan. Karena usaha industri mempunyai banyak aspek bagi pengembangan ekonomi negara dan bangsa.

Kerajinan batik desa Sidomukti merupakan industri kecil yang bergerak dalam bidang kerajinan khususnya batik tulis dengan corak utama dengan nama batik pring sedapur yang menjadi corak utama batik yang ada dipakaian, maupun seragam untuk instansi maupun sekolah di kabupaten Magetan. Dengan seiring kemajuan zaman batik sudah banyak di tinggalkan dan dilupakan oleh masyarakat terutama para anak muda karena dianggap pakaian dengan corak yang ketinggalan zaman. Tetapi akhir akhir ini pakaian dengan corak batik sangat digemari oleh masyarakat dan juga sebagai pakaian wajib pada instansi, sekolah maupun di perguruan tinggi. Dimana batik bukan hanya merupakan corak gambaran yang ada dipakaian maupun kain, melainkan batik merupakan warisan budaya bangsa yang patut dilestarikan dimana batik juga sebagai simbol bangsa yang telah diakui oleh dunia. Batik pring sedapur merupakan batik tulis yang telah lama ada di Magetan, dimana batik dengan motif pring sedapur memiliki warna dan corak yang unik berbeda dengan batik solo dan pekalongan yang memiliki corak tradisional dan lekuk - lekuk yang simetris, tapi pada batik pring sedapur memiliki motif dan warna lebih segar, di mana batik pring sedapur menjadi salah satu batik favorit Presiden Susilo Bambang Yudhoyono. Industri kecil kerajinan batik tulis pring sedapur berada di desa Sidomukti kecamatan Plaosan kabupaten Magetan.

Moeheriono (2009:60) berpendapat bahwa kinerja atau perfomance merupakan gambaran mengenai tingkat pencapaian pelaksanaan suatu program kegiatan atau kebijakan dalam mewujudkan sasaran, tujuan, visi, dan misi organisasi yang dituangkan melalui perencanaan strategis suatu organisasi. Indikator untuk kinerja karyawan adalah nilai, alat ukur, kuantitatif, kualitatif, dan informasi.

"Menilai kinerja yang dihasilkan tenaga kerja berdasarkan deskripsi pekerjaan yang telah di tetapkan pada saat melaksanakan kegiatan analisis pekerjaan." (Siswanto Sastrohadiwiryo, 2003:231).

Sedangkan menurut Sedarmayanti (2011: 358) Hasil kerja yang dapat dicapai seseorang / sekelompok orang dalam organisasi (kuantitatif dan kualitatif), sesuai kewenangan dan tugas tanggung jawab masingmasing, dalam upaya mencapai tujuan organisasi bersangkutan secara legal, tidak melanggar hukum dan sesuai moral dan etika. Tujuan Penilaian Kinerja:

Siswanto Sastrohadiwiryo (2003: 233) penilaian kinerja dilakukan dengan tujuaan sebagai berikut:

1) Sumber data untuk perencanaan kete- 
nagakerjaan dan kegiatan pengembangan jangka panjang bagi perusahaan yang bersangkutan.

2) Nasihat yang perlu disampaikan kepada para tenaga kerja dalam perusahaan

3) Alat untuk memberikan umpan balik (feed back) yang mendorong ke arah kemajuan dan kemungkinan memperbaiki/meningkatkan kualitas kerja bagi para tenaga kerja .

4) Landasan/bahan informasi dalam pengambilan keputusan pada bidang ketenagakerjaan, baik promosi, mutasi, maupun kegiatan ketenagakerjaan lainnya.

Secara khusus dan spesifik manajemen kinerja menurut Surya Dharma (2005: 29) bertujuan:

1) Memperoleh peningkatan kinerja yang berkelanjutan

2) Bertindak sebagai daya dongkrak untuk perubahan yang lebih berorientasi kinerja

3) Meningkatkan motivasi dan komitmen karyawan

4) Memungkinkan individu untuk mengembangkan kemampuan, meningkatkan kepuasan kerja dan mencapai potensi pribadi yang bermanfaat bagi individu dan organisasi.

Mengukur tingkat capaian tujuan dan sasaran organisasi, menganalisis hasil pengukuran kinerja yang dapat diimplementasikan dengan membandingkan tingkat capaian tujuan dan sasaran organisasi. (Moeheriono, 2009: 62)

Faktor Kinerja:

Menurut sedarmayanti (2011: 391) faktor kinerja terdiri dari

1) Faktor internal (disposisional) adalah faktor yang dihubungkan dengan sifat seseorang (misal: kinerja seseorang baik karena mempunyai kemampuan tinggi, tipe pekerja keras. Seseorang mempunyai kinerja jelek disebabkan orang tersebut mempunyai kemampuan rendah dan tidak memiliki upaya memperbaiki kemampuannya.
2) faktor eksternal mempengaruhi kinerja seseorang, berasal dari lingkungan, seperti: prilaku, sikap, tindakan rekan kerja, bawahan/ pimpinan, fasilitas kerja, iklim organisasi.

Faktor Yang Mempengaruhi Kinerja:

1) Faktor kemampuan: terdiri dari kemampuan potensi (IQ) dan kemampuan reality knowledge + skill): pimpinan dan karyawan yang memiliki IQ di atas ratarata (IQ 110 - 120), apalagi IQ superior, very superior, gifted, dan genius dengan pendidikan memadai untuk jabatan dan terampil dalam mengerjakan pekerjaan, maka akan lebih mudah mencapai kinerja maksimal.

2) Faktor motivasi: sikap (attitude) pimpinan dan karyawan terhadap situasi kerja dilingkungan organisasi.

a) Mereka yang bersikap positif terhadap situasi kerja, bersikap negatif terhadap situasi kerja, menunjukkan motivasi kerja rendah.

b) Situasi kerja mencakup: hubungan kerja, fasilitas kerja, iklim kerja, kebijakan pimpinan, pola kepemimpinan kerja, kondisi kerja. (Sedarmayanti, 2011:390)

Alex Soemadji Nitisemito (1996:109) berpendapat bahwa lingkungan kerja adalah segala sesuatu yang ada di sekitar pekerja dan yang dapat mempengaruhi dirinya dalam menjalankan tugas-tugas yang di bebankan. Indikator untuk lingkungan kerja adalah pewarnaan ruang, sirkulasi udara, kebersihan, penerangan, dan kebisingan.

"Peningkatan produktivitas kerja operator sangat dipengaruhi oleh kondisi lingkungan kerja fisik. Upaya peningkatan produktivitas kerja sama dengan peningkatan pengelolaan lingkungan kerja fisik yang efisien dan efektif'. (Rika Ampuh, 2009: 247)

Sukanto dan Indriyo (2000: 151) "Lingkungan kerja yang buruk akan mempengaruhi pekerja, produktivitas kerja menjadi menurun, karena pekerja merasa terganggu dalam pekerjaannya, hingga tidak 
dapat mencurahkan perhatian penuh terhadap pekerjaannya".

Sementara itu menurut Agus Ahyari (1986: 125-126)

1) Lingkungan kerja di dalam suatu perusahaan sangat penting untuk diperhatikan oleh manajemen perusahaan. Penyusunan suatu sistem produksi yang baik tidak akan dapat dilaksanakan dengan efektif apabila tidak didukung dengan lingkungan kerja yang memuaskan didalam perusahaan yang bersangkutan.

2) Lingkungan kerja yang memuaskan bagi para karyawan perusahaan yang bersangkutan akan dapat meningkatkan gairah kerja di dalam perusahaan yang bersangkutan tersebut. Demikian pula sebaliknya, lingkungan kerja yang sangat tidak memuaskan akan dapat mengurangi gairah kerja dan menurunkan tingkat produktivitas kerja para karyawan yang bekerja di dalam perusahaan yang bersangkutan.

Tujuan Pengelolaan Lingkungan Kerja

Agus Ahyari, (1986: 126) tujuan lingkungan kerja adalah

1) Untuk mendorong para karyawan tersebut untuk bekerja dengan sebaik-baiknya, sehingga pelaksanaan proses produksi di dalam perusahaan tersebut akan dapat berjalan dengan baik pula.

2) Meningkatkan gairah kerja para karyawan perusahaan dan meningkatkan tingkat produktifitas kerja para karyawan.

"Mengatur keadaan lingkungan kerja karyawan agar diperoleh kenaikan produktivitas dan berkurangnya biaya produksi tiap satuan”. (Sukanto dan Idriyo, 2000: 151)

Sedangkan menurut Rika Ampuh (2009: 247). Masalah lingkungan kerja fisik di lantai produksi sangat penting karena menyangkut pencapaian target produksi. Pekerjaan yang sangat bergantung pada operator. Dalam hal ini tipe manual atau semiotomatis, akan membutuhkan pekerja atau operator handal. Handal yang dimaksud adalah kondisi pekerja yang sehat, kesehatan dan keselamatan pekerja juga menjadi tanggung jawab perusahaan. Salah satunya dengan menciptakan lingkungan kerja fisik di lantai produksi yang ergonomis.

Lingkungan kerja merupakan tempat di mana semua karyawan ataupun pekerja suatu perusahan melakukan pekerjaan sesuai yang telah dibebankan oleh perusahaan. Lingkungan kerja secara langsung maupun tidak langsung sangat mempengaruhi kerja para karyawan dalam menyelesaikan tugastugasnya, oleh sebab itu maka para manajer perusahaan perlu memperhatikan masalah lingkungan kerja para karyawan terutama dalam bidang produksi supaya tercipta suasana kerja yang kondusif yang dapat berpengaruh terhadap kinerja para karyawan dan meningkatkan produktivitas perusahaan.

Menurut Sedarmayanti (2009: 27) mengatakan manusia akan mampu melaksanakan kegiatannya dengan baik, sehingga dicapai suatu hasil yang optimal, apabila diantaranya ditunjang oleh suatu kondisi lingkungan yang sesuai. Suatu kondisi lingkungan dikatakan baik atau sesuai apabila manusia dapat melaksanakan kegiatannya secara optimal, sehat, aman, dan nyaman.

Kinerja karyawan merupakan suatu pencapaian dari para karyawan dalam melaksanakan tugas dan tuntutan dari perusahaan. Kinerja merupakan hasil kerja dari manusia, yang mengolah dan menghasilkan barang menjadi hasil produksi perusahaan. Sebagaimana kinerja karyawan yang baik dan meningkatnya produktivitas perusahaan para karyawan dibutuhkan berbagai macam kebutuhan kerja yang bertujuan untuk mendorong semangat kerja dan kegairahan kerja dalam menjalankan suatu pekerjaan. Kebutuhan dari karyawan ini dipengaruhi oleh berbagai faktor seperti jumlah dan komposisi dari kompensasi yang di berikan, penempatan yang tepat, pelatihan, rasa aman, mutasi, promosi, lingkungan kerja, dan maih banyak faktor lain. Terutama untuk perusahaan yang berjalan di bidang produksi harus dapat memahami tentang 
lingkungan kerja karyawan yang berdampingan dengan alat produksi dalam mengerjakan pekerjaannya. Untuk itu para manajemen harus memperhatikan masingmasing faktor tersebut supaya ada peningkatan produktivitas dan kemajuan untuk masa depan perusahaan.

Sudah tentu bahwa dengan adanya lingkungan kerja yang baik, maka kinerja karyawannya meningkat dan para karyawan memiliki gairah kerja, dan semangat kerja yang tinggi dalam mengerjakan tugas-tugas yang dibebankan oleh perusahaan, untuk meningkatkan ataupun menumbuh kembang-kan perusahaan supaya lebih maju dan baik lagi.

\section{METODELOGI PENELITIAN}

Penelitian ini peneliti mengadakan penelitian pada Industri Kecil Kerajinan Batik Di Desa Sidomukti Kecamatan Plaosan Kabupaten Magetan tepatnya di balai desa Sidomukti. Pertimbangan peneliti memilih tempat penelitian ini antara lain:

a. Belum pernah diadakan penelitian yang sejenis dengan penelitian yang dilakukan peneliti, sehingga diharapkan hasil penelitian lebih bermanfaat.

b. Lokasi industri kecil tersebut mudah dijangkau karena tempatnya strategis.

c. Adanya kerjasama yang baik dari pihak industri kecil kerajinan batik.

d. Tersedianya data yang mendukung untuk penelitian ini.

Rancangan penelitian yang digunakan dalam penelitian ini adalah kausal komparatif (causal comporative research). Penelitian ini bertujuan untuk menyelidiki kemungkinan sebab-akibat berdasarkan pengamatan tehadap akibat yang ada, mencari kembali fakta yang mungkin menjadi penyebab melalui data tersebut. Penelitian kausal komparatif bersifat "ex post facta artinya dikumpulkan setelah semua kejadian yang diperoleh berlangsung atau lewat" (Cholid Narbuko dan Abu Achmadi, 2003: 49).

Metode yang digunakan dalam penelitian ini adalah penelitian kuantitatif.
Menurut Iqbal Hasan (2006: 30) "analisis kuantitatif adalah analisis yang menggunakan alat analisis bersifat kuantitatif, yaitu alat analisis yang menggunakan model-model, seperti model matematika (misalnya fungsi multifariat), model statistik, dan ekonometrik". Hasil analisis disajikan dalam bentuk angka-angka yang kemudian dijelaskan dan diinterprestasikan dalam suatu uraian.

Menurut Suharsimi Arikunto (2010: 173) "Populasi adalah keseluruhan objek penelitian". Adapun yang menjadi populasi dalam penelitian ini adalah karyawan pada Industri Kecil Kerajinan Batik Di Desa Sidomukti Kecamatan Plaosan Kabupaten Magetan yang berjumlah 65 karyawan. Suharsimi Arikunto (2010: 174) berpendapat "Sampel adalah sebagian atau wakil populasi yang diteliti". Sedangkan menurut Cholid Narbuko dan Abu Achmadi (1997: 110) "memberikan pedoman sebagai berikut, Apabila populasi cukup homogen (serba sama), terhadap populasi di bawah 100 dapat dipergunakan sampel sebesar $50 \%$, di atas 1,000 sebesar $15 \%$. Adapun yang menjadi sampel penelitian pada seluruh karyawan yang bekerja pada Industri Kecil Kerajinan Batik Di Desa Sidomukti Kecamatan Plaosan Kabupaten Magetan berjumlah 65 orang dengan mengambil $50 \%$ jumlah karyawan yang lebih senior dengan masa kerja lebih lama yaitu menjadi 35 karyawan. Dalam penelitian ini skala likert digunakan agar mempermudah responden dalam menjawab pertanyaan kemudian responden menjawab pertanyaan sesuai dengan kode yang ada dalam kuesioner. Instrumen yang digunakan dalam penelitian ini yaitu angket dengan skala likert. Sugiyono, (2007: 94) menyatakan bahwa rentang skala likert adalah sangat setuju, setuju, ragu-ragu, tidak setuju, dan sangat tidak setuju.

\section{HASIL PENELITIAN}

Variabel Lingkungan kerja, dengan jumlah N 35 orang/karyawan dalam statistik deskriptifnya sebagai berikut: (a) Nilai 
jumlah total skor sebesar1667; (b) Nilai mean sebesar 47,63; (c) Nilai median sebesar 49,00; (d) Nilai modus sebesar 50; (e) Nilai standar deviasi sebesar 2,860; (f) Nilai minimum sebesar 40; (g) Nilai maximum sebesar 50. Dari hasil deskripsi stastistik diatas maka lingkungan kerja di industri kecil kerajinan batik dapat dikatakan baik dan kondusif.

Variabel Kinerja karyawan, dengan jumlah N 35 orang/Karyawan dalam statistik deskriptifnya sebagai berikut: (a) Nilai jumlah total skor sebesar 1696; (b) Nilai mean sebesar 48,46; (c) Nilai median sebesar49,00; (d) Nilai modus sebesar 50; (e) Nilai standar deviasi sebesar 1,804 ; (f) Nilai minimum sebesar 44; (g) Nilai maximum sebesar 50. Dari hasil deskripsi statistik diatas maka kinerja karyawan di industri kecil kerajinan batik Sidomukti sangat baik.

\section{a. Hasil pengujian validitas}

Uji validitas dilakukan dengan menggunakan rumus Pearson Product Moment.Uji validitas merupakan ukuran yang menunjukkan tingkat-tingkat kevalidan atau kesahihan suatu instrument. Sebuah instrument dikatakan valid apabila mampu mengukur apa yang diinginkan dan dapat mengungkapkan data dari variabel yang diteliti secara tepat. Uji validitas dalam penelitian ini adalah untuk menguji kuesioner lingkungan kerja dan kinerja karyawan.

Data diolah dengan SPSS for windows 16.0 dapat dikatakan bahwa semua item dalam kuesioner Lingkungan kerja adalah valid. Hal ini dapat diketahui dari nilai $r_{x y}$ lebih besar dari $r_{\text {tabel }}\left(r_{x y} \geq r_{\text {tabel }}\right)$. Dari hasil tersebut dapat disimpulkan bahwa semua soal yang ada dalam kuesioner. Lingkungan kerja dapat digunakan dalam penelitian.

b. Hasil uji reliabilitas Lingkungan Kerja dan Kinerja Karyawan

Uji reliabilitas merupakan suatu instrument yang dapat dipercaya untuk digunakan sebagi alat pengumpul data sehingga tidak bersifat tendensius atau mengarah responden untuk memilih jawaban-jawaban tertentu.

Hasil uji reliabilitas terhadap kuesioner Lingkungan kerja diperoleh dari Cronbach's Alpha sebesar 0,768. Karena nilai Cronbach's Alpha lebih dari 0,7 dapat disimpulkan bahwa data yang dikumpulkan melalui kuesioner Lingkungan kerja dapat dipercaya. Oleh karena lingkungan kerja dapat digunakan sebagai alat pengumpul data untuk penelitian.

Hasil uji reliabilitas terhadap kuesioner kinerja karyawan diperoleh dari Cronbach's Alpha sebesar 0,813. Karena nilai Cronbach's Alpha lebih dari 0,7 dapat disimpulkan bahwa data yang dikumpulkan melalui kuesioner kinerja karyawan dapat dipercaya. Oleh karena itu Kinerja karyawan dapat digunakan sebagai alat pengumpul data untuk penelitian.

\section{Analisis Data}

Dalam penelitian ini analisis yang digunakan untuk mencari pengaruh Lingkungan kerja terhadap Kinerja karyawan menggunakan regresi linier. Dengan uji regresi linier sederhana dapat diketahui uji hipotesis menggunakan alat bantu SPSS for windows 16.0.

a. Uji Korelasi

Uji korelasi digunakan untuk mencari keeratan hubungan antara lingkungan kerja dengan kinerja karyawan. Hipotesis dalam uji korelasi adalah sebagai berikut:

(1) $\mathrm{H}_{\mathrm{o}}$ ditolak apabila nilai $\operatorname{Sig}_{h i t} \leq S i g_{\text {prob }}$ atau $r_{\text {hitung }} \geq r_{\text {tabel }}$ dapat diartikan ada hubungan Lingkungan kerja terhadap Kinerja karyawan pada industri kecil kerajinan batik Sidomukti.

(2) $\mathrm{H}_{\mathrm{O}}$ diterima apabila nilai $S i g_{\text {hit }} \geq S i g_{\text {prob }}$ atau $r_{\text {hitung }} \leq r_{\text {tabel }}$ dapat diartikan tidak ada hubungan Lingkungan kerja terhadap Kinerja karyawan pada industri kecil kerajinan batik Sidomukti. 
Dari hasil uji korelasi diperoleh nilai $r_{\text {hitung }}$ sebesar 0,393 sedangkan $r_{\text {tabel }}$ sebesar 0,334. Dilain pihak nilai Sig $_{\text {hit }}$ sebesar 0,393 dan $\mathrm{Sig}_{\text {prob }}$ sebesar 0,334. Hal ini berarti nilai $\mathrm{r}$ hitung $\geq r_{\text {tabel }}(0,393 \geq 0,334)$ atau $\operatorname{Sig}_{\text {hit }} \leq \operatorname{Sig}_{\text {prob }}$ $(0,000 \leq 0,05)$. Dapat diartikan bahwa ada hubungan antara Lingkungan kerja terhadap kinerja karyawan pada industri kecil batik Sidomukti.

Di lain pihak dalam uji determinasi yang diperoleh $\mathrm{R}^{2}$ ( $\mathrm{R}$ Square) atau koefisien determinasi yang digunakan untuk mengetahui seberapa besar prosentase Lingkungan kerja terhadap Kinerja karyawan. Berdasarkan tabel 4.8. tersebut di atas dapat diketahui nilai $\mathrm{R}^{2}$ adalah sebesar $15,40 \%$. Jadi sumbangan pengaruh dari lingkungan kerja terhadap Kinerja karyawan yaitu 15,40\% sedangkan sisanya $84,60 \%$ dipengaruhi oleh faktor lain yang tidak diteliti.

b. Uji F/Uji Fisher

Uji Fisher digunakan untuk mencari pengaruh lingkungan kerja terhad kinerja Karyawan.

Hipotesis uji fisher yang digunakan adalah sebagai berikut:

(1) $\mathrm{H}_{\mathrm{O}}$ ditolak bila nilai $F_{\text {hitung }} \geq F_{\text {tabel }}$ atau $\mathrm{Sig}_{\text {hit }} \leq \mathrm{Sig}_{\text {prob }}$ berarti ada pengaruh Lingkungan kerja terhadap kinerja karyawan pada industri kecil kerajinan batik Sidomukti.

(2) $\mathrm{H}_{\mathrm{O}}$ diterima bila nilai $F_{\text {hitung }} \leq F_{\text {tabel }}$ atau $S i g_{h i t} \geq S i g_{\text {prob }}$ berarti tidak ada pengaruh Lingkungan kerja terhadap kinerja karyawan pada industri kecil kerajinan batik Sidomukti.

Dari hasil uji F/Fisher dapat diketahui nilai $F_{\text {hitung }}$ sebesar 6,024 sedangkan nilai $F_{\text {tabel }}$ sebesar 4,12. Dilain pihak nilai $\operatorname{Sig}_{\text {hit }}$ sebesar 0,000 dan $\mathrm{Sig}_{\text {prob }}$ sebesar 0,05. Hal ini berarti bahwa nilai $F_{\text {hitung }} \geq F_{\text {tabel }}(6,024 \geq 4,12)$ dan Sig hit $\leq \operatorname{Sig}_{\text {prob }}(0,000 \leq 0,05)$. Hal ini dapat dikatakan bahwa $\mathrm{H}_{\mathrm{O}}$ ditolak, artinya ada pengaruh Lingkungan kerja terhadap Kinerja karyawan pada Industri kecil kerajinan batik
Sidomukti.

Selain digunakan untuk mencari pengaruh uji Fisher atau Anova ini digunakan untuk uji linearitas. Karena $F_{\text {hitung }}$ sebesar $6,024 \geq \mathrm{F}_{\text {tabel }}$ sebesar 4,12. Yang artinya ada hubungan yang linear antar dua variabel Lingkungan kerja dengan Kinerja karyawan.

c. Ujit

Uji t digunakan untuk mengetahui beda pengaruh antara Lingkungan kerja terhadap Kinerja karyawan.

Hipotesis yang digunakan dalam uji t adalah sebagai berikut:

(1) $\mathrm{H}_{\mathrm{O}}$ ditolak bila nilai $t_{\text {hitung }} \geq t_{\text {tabel }}$ atau $\mathrm{Sig}_{\text {hit }} \leq \operatorname{Sig}_{\text {prob }}$ berarti ada beda pengaruh Linngkungan kerja terhadap kinerja karyawan pada industri kecil kerajinan batik Sidomukti.

(2) $\mathrm{H}_{\mathrm{O}}$ diterima bila nilai $t_{\text {hitung }} \leq t_{\text {tabel }}$ atau $S i g_{\text {hit }} \geq S i g_{\text {prob }}$ berarti tidak ada beda pengaruh Lingkungan kerja terhadap kinerja karyawan pada industri kecil kerajinan batik Sidomukti.

Dari hasil uji $\mathrm{t}$ diperoleh nilai $\mathrm{t}_{\text {hitung }}$ sebesar 2,454 $\geq \mathrm{t}_{\text {tabel }}$ sebesar 0,681 atau nilai Sig $_{\text {hit }}$ sebesar $0,000 \leq \operatorname{Sig}_{\text {prob }} 0,05$. Hal ini berarti nilai $t_{\text {hitung }} \geq t_{\text {tabel }}(2,454 \geq 0,681)$ atau $\operatorname{Sig}_{\text {hit }} \leq \operatorname{Sig}_{\text {prob }}(0,000 \leq 0,05)$. Dari hasil uji t tersebut dapat dikatakan bahwa $\mathrm{H}_{\mathrm{O}}$ ditolak artinya ada beda pengaruh Lingkungan kerja terhadap kinerja karyawan pada industri kecil kerajinan batik Sidomukti.

Lebih lanjut apabila dilihat dalam persamaan regresi diperoleh persamaan nilai $\mathrm{Y}=17,446+0,623 \mathrm{X}$. Dari persamaan garis regresi tersebut dapat dilihat jika Lingkungan kerja meningkat sebanyak $1 \%$ maka jumlah kinerja karyawan meningkat pula sebesar $0,623 \%$, sedangkan faktor lainnya tetap.

\section{PENUTUP}

\section{Simpulan}

Berdasarkan analisis data dan pembahasan yang telah diuraikan pada bab sebelumnya dapat diambil simpulan sebagai 
berikut:

1. Lingkungan kerja memiliki nilai rata-rata sebesar 47,63 dengan nilai maksimum 50, nilai minimum 40 , standar deviasi 2,860 , median 49,00, dan modus sebesar 50. Dari hasil deskripsi variable lingkungan kerja diketahui bahwa responden cenderung setuju terhadap lingkungan kerja yang baik. Karena dimana lingkungan kerja yang baik dan kondusif dapat meningkatkan kinerja para karyawannya dalam proses produksi yang dibebankan dari perusahaan.

2. Kinerja karyawan memiliki rata-rata sebesar 48,46 dengan nilai maksimum 50, nilai minimum 44 , standar deviasi 1.804 , median 49,00 dan modus sebesar 50. Dari hasil deskripsi variable kinerja karyawan diketahui bahwa responden cenderung mempunyai nilai rata-rata 48,46 yang berarti suatu lingkungan kerja yang baik dapat mendukung kinerja para karyawannya dalam proses produksi yang dibebankan perusahaan tersebut.

3. Ada pengaruh Lingkungan kerja terhadap Kinerja karyawan, hal ini dibuktikan dalam hasil anlisis regresi pada uji korelasi, uji F, dan uji t. Pada uji korelasi diperoleh nilai $r_{\text {hitung }}$ sebesar 0,393 sedangkan $r_{\text {tabe }}$ sebesar 0,334. Dilain pihak nilai Sig $_{\text {hit }}$ sebesar 0,000 dan Sig prob $_{\text {sebesar }}$ 0,05 . Hal ini berarti bahwa nilai $r_{\text {hitung }} \geq r_{\text {tabel }}$ $(0,393 \geq 0,334)$ atau $\operatorname{Sig}_{\text {hit }} \leq \operatorname{Sig}_{\text {prob }}(0,000 \leq$ $0,05)$. Sementara pada uji fisher diperoleh nilai $\mathrm{F}_{\text {hitung }}$ sebesar 6,024 sedangkan nilai $\mathrm{F}_{\text {tabel }}$ sebesar 4,12. Dilain pihak nilai $\mathrm{Sig}_{\text {hit }}$ sebesar 0,000 dan $\mathrm{Sig}_{\text {prob }}$ sebesar 0,05. Hal ini berarti bahwa nilai $F_{\text {hitung }} \geq \mathrm{F}_{\text {tabel }}(6,024 \geq$ $4,12)_{\text {dan }} \operatorname{Sig}_{\text {hit }} \leq \operatorname{Sig}_{\text {prob }}(0,000 \leq 0,05)$. Dan pada uji $t$ diperoleh nilai $t_{\text {hitung }}$ sebesar $2,454 \geq \mathrm{t}_{\text {tabel }}$ sebesar 0,681 atau nilai $\mathrm{Sig}_{\text {hit }}$ sebesar $0,000 \leq \operatorname{Sig}_{\text {prob }} 0,05$. Hal ini berarti nilai $t_{\text {hitung }} \geq t_{\text {tabel }}(2,454 \geq 0,681)$ atau Sig $_{\text {hit }}$ $\leq \operatorname{Sig}_{\text {prob }}(0,000 \leq 0,05)$. Dari analisis regresi diperoleh persamaan $\mathrm{Y}=17,446+$ $0,623 \mathrm{X}$ berarti apabila lingkungan kerja sebanyak $1 \%$ maka kinerja karyawan akan meningkat pula sebesar 0,623, sedangkan faktor lainnya dianggap tetap. Dari hasil koefisien determinasi atau $\mathrm{R}^{2}$ diperoleh prosentase sebesar 15,40\% yang dipengaruhi oleh lingkungan kerja, sedangkan prosentase sebesar 84,60\% berasal dari faktor-faktor tertentu.

\section{Saran}

1. Bagi Industri kecil kerajinan batik Sidomukti

- Hendaknya para pimpinan ataupun manajer untuk lebih memperhatikan kebutuhan para karyawan, dalam menunjang kinerja karyawannya.

- Tumbuh kembang suatu perusahaan dipengaruhi oleh kinerja karyawan untuk itu kinerja akan baik dibutuhkan suatu Lingkungan kerja yang baik juga, karena lingkungan kerja merupakan salah satu faktor yang dapat meningkatkan kinerja para karyawan dalam menyelesaikan tugas maupun beban yang telah diberikan oleh perusahaan, meskipun hanya mempunyai prosentase $15,40 \%$.

- Kinerja karyawan akan meningkat dipengaruhi oleh suatu lingkungan kerja yang baik, nyaman serta kondusif.

2. Bagi Karyawan

- Karyawan hendaknya lebih terbuka memberi saran kepada pimpinan ataupun manajer tentang kebutuhannya dalam peningkatan kinerja seperti suatu lingkungan kerja yang baik, nayama, serta kondusif sesuai yang dibutuhkan dalam menunjang kinerjanya.

- Karyawan juga harus lebih memperhatikan dan menjaga lingkungan kerja yang ditempati agar tidak mengganggu pekerjaan, seperti kebersihan tempat kerja untuk menjaga kesehatannya. 
- Lingkungan kerja yang baik dapat bermanfaat bagi diri karyawan maupun tumbuh kembang suatu perusahaan.

\section{DAFTAR PUSTAKA}

Agus Ahyari. 1986. Manajemen Produksi Perencanaan Sistem Produksi. Yogyakarta:BPFE

Alex Nitisemito. 1996. Manajemen Personalia. Jakarta: Ghalia Indonesia

Cholid Narbuko dan Abu Achmadi. 1999. Metodologi Penelitian. Jakarta: PT. Bumi Aksara

Cholid Narbuko dan Abu Achmadi. 2003. Metodologi Penelitian. Jakarta: PT. Bumi Aksara

Dale Furtwengler. 2000. Penilaian Kinerja. Terjemahan oleh Fandy Tjiptono. 2002. Yogyakarta:ANDI Copyright

Husaini Usman dan Purnomo Setyadi Akbar. 2004. Metodologi Penelitian Sosial. Jakarta: PT Bumi Aksara

Iqbal Hasan. 2006. Analisis Data Penelitian dengan Statistik. Jakarta: PT. Bumi Aksara

Jaka Permana. 2006. Membangun Industri Kecil Di Desa. Bandung: CV. Putra Setia
Moeheriono. 2009. Pengukuran Kinerja Berbasis Kompetensi. Bogor: Ghalia Indonesia

Rika Ampuh. 2009. Manajemen Pabrik. Jakarta: Bumi Aksara

Sukanto Reksohadiprodjo dan Indriyo Gitosudarmo. 2000. Manajemen Produksi. Yogyakarta: BPFE

Sedarmayanti. 2009. Tata Kerja Dan Produktivitas Kerja. Bandung: CV. Mandar Maju

Sedarmayanti. 2011. Membangun Dan Mengembangkan Kepemimpinan Serta Meningkatkan Kinerja Untuk Meraih Keberhasilan. Bandung: PT. Refika Aditama

Siswanto Sastrohadiwiryo. 2005. Manajemen Tenaga Kerja Indonesia. Jakarta: PT. Bumi Aksara

Surya Dharma. 2005. Manajemen Kinerja. Yogyakarta: Pustaka Pelajar

Suharsimi Arikunto. 2010. Prosedur Penelitian. Jakarta: PT. Rineka Cipta

Sugiyono. 2007. Metode Penelitian Kuantitatif, Kualitatif dan R\&D. Bandung: CV Alfabeta

Sugiyono. 2004. Metode Penelitian Administrasi. Jl. Gegerkalong Hilir: CV. Alfa Beta 